\title{
Muhammadiyah's View of the Pancasila State in the Dynamics of Diversity in Indonesia after the 2015 Congress
}

\author{
Muhammad Lukman Hakim ${ }^{1}$, David Efendi ${ }^{2}$, Alam Mahadika ${ }^{3^{*}}$ \\ ${ }^{123}$ Departement of Governmental Science, Faculty of Social and Political Sciences, \\ Muhammadiyah University of Yogyakarta \\ *Corresponding author: ${ }^{1}$ lukmanhakim@gmail.com, ${ }^{2}$ defendi83@gmail.com, \\ $3^{*}$ mahadikaalam@gmail.com
}

\begin{abstract}
Indonesia is a multiculturalist country by placing Pancasila as the main milestone in formulating all attitudes towards the nation and state, which are expected to inherit a nation's noble and noble culture. Pancasila contains values that are very noble and do not conflict with religious and social values. The motto "Different but still one" unites differences in religion, race, ethnicity, and culture, from Sabang to Merauke. So that in the future, it will prevent Indonesia from various threats that damage the nation's sovereignty, such as separatism, treason, terrorism, and national diseases that can erode the joints of the state later. Muhammadiyah is an important part of the nation, one of which has a role in participating in caring for and preserving this noble and noble culture of the country. With various contributions in the field of thought, such as the "Pancasila State" as a progressive Indonesian as Darul Ahdi wa al-Syahadah, progressing Islam, Insha Allah will be able to nurture the noble values of Pancasila.
\end{abstract}

Keywords: Diversity; Muhammadiyah; Pancasila; Tolerance

\section{Introduction}

The existence of Pancasila cannot be separated from the involvement of Muhammadiyah. Even since the formulation of Pancasila until now, Muhammadiyah has always been involved in it. Muhammadiyah elites at the 
beginning of independence such as Kahar Muzakkir, Kasman Singodimedjo, and $\mathrm{Ki}$ Bagus Hadikusumo were figures from Muhammadiyah whose services could not be forgotten for the Indonesian nation and state. Especially Ki Bagus Hadikusumo, who was one of the key figures in Pancasila's birth, especially with the first principle of "God Almighty," which was the suggestion of Ki Bagus Hadikusumo as a substitute for the phrase obligation to carry out Islamic Sharia for adherents. This historical evidence certainly proves that Muhammadiyah is not tempted to replace the Pancasila system in the Republic of Indonesia ${ }^{1}$. Muhammadiyah, as one of the Islamic religious organizations in caring for diversity, does not seem to want to fall into one extreme axis, such as the extreme right, which is known to be too textual to be considered anti-change and tends to be suspicious of various products of thought and movements born from the west. Meanwhile, the extreme left is known to be very appreciative of western ideas and directions. It is not uncommon for this pole to be considered or the accomplice of the west itself. ${ }^{2}$.

Muhammadiyah is also not a place for liberal - secular thoughts and movements that prioritize freedom and remove religion from the space of activity. For Muhammadiyah, the release has a high end as a basic right, but it is not freedom without limits. Muhammadiyah's freedom is limited freedom that takes into account the existence of other parties. Secular thoughts and movements are very much at odds with Muhammadiyah because they can lead to a permissive lifestyle. So then Muhammadiyah positioned itself as the Moderate / Middle Ages leader who did not aspire to an Islamic model that stood on the extreme poles. So that in this context and model Muhammadiyah will find it easier to take care of Indonesia's diversity ${ }^{3}$. Haidar Nashir explained the different positions of Muhammadiyah from the textualists at one end of the spectrum. In certain contexts, Muhammadiyah is very textual, and in other contexts, Muhammadiyah is very open. The approach that is often used by Muhammadiyah often depends on the context. The choice to become a moderate movement was not a coincidence but was decided on a random and planned basis. The argument used by Muhammadiyah as an average movement is explained in verse Al-Baqarah / 2: 143 "And so we make you the middle ummah." A hadith of the Prophet

1 Hidayat,Syamsul.2016.”Negara Pancasila Sebagai Daruk 'Ahdi Wasy Syahadah Wawasan dan Kontribusi Muhammadiyah Bagi NKRI. Tajdid, 14(1), 12-17.

2 Nashir,Haedar.2010.Muhammadiyah Gerakan Pembaharuan.Suara Muhammadiyah.Yogyakarta. Page 46.

3 Nashir, Haedar. 2010. Muhammadiyah Gerakan Pembaharuan. Suara Muhammadiyah. Yogyakarta. Page $46-47$. 
confirms the poem; the best thing is that business is the middle. These verses and Hadiths strengthen each other. Muslims are destined to be moderates who are not extreme. Meanwhile, the Prophet's Hadith explains that the choice of the best thoughts and movements is certainly not excessive. The ideal form of state-approved by Muhammadiyah is the Republic of Indonesia by functioning Pancasila as the state philosophy. Muhammadiyah, through the wasathiyah (Moderate) movement, automatically operates to guard the unity of the Republic of Indonesia. Not free from conflicts and contradictions related to Pancasila as Indonesia's ideology and diversity, which is slightly tainted with extremism from certain fanatical groups. Therefore Muhammadiyah does not want to fall into all the understandings or the existence of anti-Pancasila organizations. Not only does Muhammadiyah reject anti-Pancasila ideas, but Muhammadiyah also firmly rejects Communist ideology. Muhammadiyah also left various separatist movements that wanted to establish their state and understandings that were harmful to the Republic of Indonesia.

At the beginning of independence, when Indonesia was faced with the rise of political currents, which then divided Indonesia into several ideological streams, namely the Islamic, Nationalist, Socialist and Communist schools. These streams then took the form of a Political Party, namely the Indonesian Nationalist Party (PNI), a party that represented Nationalism and was led by Soekarno, then the Indonesian Muslimin Council Syuro (Masyumi) and Nadhatul Ulama (NU), which were based on Islam, then the Indonesian Communist Party. (PKI) which represents Communism and the Indonesian Socialist Party (PSI), which means Socialism. Since then, debates and clashes between ideologies have colored Indonesia.

Then in the 2017 period, Indonesia was also marked by religious movements such as the Action to Defend Islam. This action covers three important series in the history of the Indonesian Islamic movement. The series, among others, took place at stage 1 (October 14), step 2 (November 4), stage 3 (December 2), as the culmination of the discourse on the Action to Defend Islam, which drew public attention at both the national and international levels. This marked a social, political, and symbolic event for the Indonesian state that the action occurred by some Muslims who felt insulted by the words of Basuki Tjahaja Purnama (Ahok), the Governor of Jakarta on September 27, who implanted one of the verses of the Al-Quran in the letter Al-Maidah verse 51 which was later considered to be blasphemous to Islam and led to the imprisonment of Ahok. 
On the one hand, the Action to Defend Islam, which was initiated to bring Ahok into a case against Ahok, on the one hand, this movement is a natural and obligatory thing that must be done by Muslims if their religion is defamed, while on the other hand, certain groups raise issues of intolerance, radicalism, and superstition, some say Deislamization. extending the problem, and the other side of the Defend Islam Action is considered by some Islamic activists to have begun to shift to a political movement ${ }^{4}$.

Responding to events that threaten the Republic of Indonesia from the early days of independence to Indonesia today and the emergence of several community organizations, one of which is Hizbut Tahrir Indonesia, which is rumored to want to replace the Indonesian Pancasila state system with the Khilafah system, it seems that the Government of President Jokowi's era does not want to provide opportunities for organizations. - an organization that is said by the Government to be dangerous. The Government then revises the Community Organization Law Number 17 of 2013 to avoid movements that threaten the Republic of Indonesia. However, it seems that this law has slightly hurt Indonesian democracy because it was only decided unilaterally, resulting in the revocation of the legal entity belonging to Hizbut Tahrir Indonesia.

Muhammadiyah considers that the Government Regulation instead of Law (PERPPU) has entered the political realm in the DPR RI then released Muhammadiyah's stance on PERPPU Community Organizations which urged the DPR RI to make political decisions as best as possible and wisely based on broader interests of the nation and state and support the establishment of a democratic government system by Pancasila.

Muhammadiyah's choice to become a wasathiyah movement and its views on the Pancasila State are urgently needed amid violence and the tug of war in various parts of the world. Whereas the multiple elements of the Muslim community in this context are Muhammadiyah to be the guardian needed by society such as what guarding is now required, namely: democracy, respect for human rights, uphold various forms of diversity, law enforcement indiscriminately against global terrorism and prevention of forms of violence. This escort is indeed Muhammadiyah's mission to realize the expected world order of life..

With the moderate attitude of Muhammadiyah and Muhammadiyah views on the country, Pancasila is expected to be able to bring a sense of peace

4 Khamid,Nur.2016.Bahaya Radikalisme Terhadap NKRI.Millati.Journal Of Islamic Studies and Humatinites, $1(1), 123-152$ 
and tension for the Indonesian nation, especially Muhammadiyah with many followers and cadres scattered in Indonesia, sowing the values contained in the Muhammadiyah view of Pancasila State as Darul Ahdi - Ways Syahadah, so that there is no need to have a conspiracy issue in Indonesia. This is the National Jihad of Muhammadiyah.

There are two reasons why the theme of this research is very important to be studied. First, responding to the many issues of the threat of diversity and tolerance of religious communities caused by several extremist groups, which then threaten Pancasila's establishment as the only foundation of the Indonesian nation's ideology. It cannot be denied that Pancasila is always faced with doctrines that are considered better to be installed in Indonesia, Islamic law, Communism, Secularism and various other ideologies that are clearly in the midst of the Indonesian nation, which is ready and at any time to replace Pancasila if society too apathetic about treason issues such as liberalism, radicalism, and others that already exist in Indonesia.

Both Pancasila among the general public or political parties have become commonplace and have also been widely studied byvarious researchers. Meanwhile, research on Pancasila Diversity of Tolerance in the context of Muhammadiyah as civil society has not been too much. Muhammadiyah's political attitude is not solely pluralistic. The modern, dynamic, and progressive Muhammadiyah movement does not always apply normatively that its activities must be rational. The collective leadership system shows that the absence of a single command greatly influences the variations in political attitudes of Muhammadiyah elites, for example, the birth of the National Mandate Party (PAN), which arose debates among the public regarding its relationship with Muhammadiyah. Likewise, the attitude of Muhammadiyah members towards the Jakarta charter and terrorism which is too caritative.

From the above background, several problem formulations arise, namely, how is the Muhammadiyah elite's view towards Pancasila and Diversity in Indonesia? How does Muhammadiyah respond to the dynamics of diversity in Indonesia after the 2015 Mutammar Muhammadiyah ?.

\section{Literature Review}

Several experts have conducted studies on Pancasila from various aspects. Pancasila has become an important object of research that is studied among academics and practitioners and the general public. Since the beginning, 
Pancasila's position in the life of the nation and state was placed in the top position, which was used as a source of inspiration in the country. Also, studies on radicalism, extremism, and diversity have been frequently carried out to maintain mutual tolerance and keep Indonesia's diversity intact to make the country safe and peaceful and serene as aspired by Muhammadiyah in its belief about the Pancasila State as Darul Mahdi Ways Syahadah or the State. Peaceful and prosperous.

Like his book Haedar Nashir (2010) entitled Muhammadiyah Movement of Renewal, he discusses Muhammadiyah as a reform movement. The study's focus is emphasized on the context of birth, basic ideas, organizational spirit, charity, implications, and various aspects related to the existence or essence of Muhammadiyah as an Islamic reform movement ${ }^{5}$. In this work of Haedar Nashir, it is explained in detail about theology, ideology, and the Muhammadiyah movement's model of action, which has a renewal character, which leads to modernism or Islamic reformism. This reform is realized by fighting the thinking of the people and building a progressive understanding of Islam.

Like the work of David Efendi (2010) in his book Politics of Elit Muhammadiyah: The Study of Muhammadiyah Elite Fragmentation, this book originating from the Master's thesis at Gadjah Mada University tries to see how the attitudes of the Muhammadiyah elite are not uniform in responding to political dynamics which then reinforces the division within the elite. Muhammadiyah which is divided into two camps between non-political and political centers, structural and cultural groups, which then transform into the context of political Islam and cultural Islam 6 .

According to his research content, especially on the political failure in 2004, it did not make the Muhammadiyah elite traumatized by maneuvering in the 2009 elections, even though a non-political camp emerged after the defeat of Muhammad Amin Rais. According to David, the efficiency of the Muhammadiyah elite group can be divided into four variants.

The first variant of the Political Fundamentalist group is that this group is very ideological and believes that Islam's struggle must pass through the State. The second group is the Passive Moderate; this faction says that the middle class does not want division or quarrels. They think that Islamic affairs and da'wah are

5 Nashir, Haedar. 2010. Muhammadiyah Gerakan Pembaharuan. Suara Muhammadiyah. Yogyakarta.

6 Efendi,David.2010.Politik Elit Mumammadiyah: Stdui Tentang Fragmatisme Elit Muhammadiyah. Revia Cendekia. Yogyakarta. 
far more important than political matters. The third variant is active moderates, which distinguishes passive moderates from this group looking for, gathering news, and analyzing it as material to determine their followers' political choices. Finally, the historical group tends to be flexible but has a basis for arguments and principles. Whatever the organization says they will submit to complete, they always use that premise when discussing political matters. This group thinks that preaching through Muhammadiyah is just as noble as fighting in the political arena.

The following research by Slamet Sutrisno (2006) in his work Philosophy and Ideology of Pancasila, the discussion after entering the reform era many questioned Pancasila's existence, in this case, its compatibility with the conditions of life of the nation and state of Indonesia. Pancasila is the basis of the country and as the basis for the philosophy and ideology of the Indonesian government. This means that he occupies a very fundamental position so that it becomes the basis for national life. ${ }^{7} \mathrm{n}$ his work, themes are discussed in detail regarding the relationship between Pancasila and the current context of change, such as its relationship with globalization and traditional culture about Pancasila's existence. So this work emphasizes the study of the deconstruction of Pancasila in the Reformation era and globalization, which is part of the Indonesian nation's historical life.

\section{Methods}

From the type of data, the research approach used in this study is qualitative. Qualitative research intends to understand the phenomena experienced by research subjects holistically and using descriptions in the form of words and language ${ }^{8}$. This research approach is descriptive, namely research that tries to tell the solution of existing problems. This type of qualitative descriptive research is used in this study to obtain information on the Pancasila Muhammadiyah State's views on the dynamics of diversity in Indonesia.

The subject of this research is Muhammadiyah. The object of this research is Muhammadiyah at the mid-level after Mutkamar Muhammadiyah 47 and Muhammadiyah elites who do not serve in Muhammadiyah but have a big influence on Muhammadiyah. This research's data collection techniques are documentation, techniques for collecting written data in the form of

\footnotetext{
7 Sutrisno,Slamet. 2006. Filsafat dan Ideologi Pancasila. Andi. Yogyakarta.

8 Moleong,Lexi.2007. Qualitative Research Methodology. PT Remaja Rosdakarya, Yogyakarta.
} 
Muhammadiyah Official Decrees, book manuscripts, newspapers, and others. The documentation contained can be sourced from anywhere as long as the source is clear and can be accounted for. The written document will be used in this research.

Data analysis techniques are very important in qualitative research so that the data obtained is processed and provided in descriptive and narrative form to make it easier for researchers to use the data; this data analysis technique uses the theory of Huberman (1992), says qualitative research for the process of analyzing data through three stages, namely Data reduction, this stage the researcher will make simpler the data obtained in the field is processed so that the raw data that is still in document form can be categorized according to the needs of the researcher, after that the presentation of the data the researcher tries to describe the existing data is arranged systematically so that the data can be used concluding, the last is drawing conclusions or verification, the researcher will make conclusions which are supported by very strong evidence at the data collection stage'

\section{Result}

\subsection{Discourse Pancasila di Muhammadiyah}

Muhammadiyah's views and commitment to strengthening Pancasila and caring for diversity have been stated in Muhammadiyah's Matan Beliefs and Life ideals. It has been said that:

Muhammdiyah invites all layers of the Indonesian nation who have received God's gift in the form of a homeland that has a source of wealth, national independence, and the Republic of Indonesia based on Pancasila and the 1945 Constitution, to jointly make a just and prosperous country that is pleasing to Allah SWT. ${ }^{10}$

In other words, Muhammadiyah has no desire to form a state other than Pancasila, including a formal Islamic government such as the Islamic Khilafah State. In this case, Muhammadiyah's position in viewing Pancasila has been confirmed by the 2012 Tanwir Muhammadiyah Bandung decision, which states that Muhammadiyah has accepted and even co-founded the Republic of

9 Huberman,Miles. 1992. Analisis Data Kualitatif. Universitas Indonesia Press. Jakarta.

10 Suara,Muhammadiyah. 2020. Matan Keyakinan dan Cita - Cita Hidup. Suaramuhammadiyah.id. https:// www.suaramuhammadiyah.id/2020/07/04/matan-keyakinan-dan-cita-cita-hidup/ 
Indonesia as a national consensus, namely as "Darul Ahdi" (Collective Treaty State) and "Darus Syahadah" (the country where Muhammadiyah embodies Islamic thought and practice).

There is no structural conflict with Pancasila as the Indonesian state's basis in the structural Muhammadiyah at the central level. Muhammadiyah, as a progressive Islamic da'wah movement, views that every point of Pancasila is in line with Islamic thoughts, and of course, divine thoughts are the main key in each of its principles. Conflicts related to Pancasila as the basis of the state occur not at the central and regional levels. This was conveyed by Din Syamsudin when Tanwir Muhammadiyah had a dialogue between Din Syamsudin and one of the local leaders and Muhammadiyah cadres in Padang. They wanted Indonesia to be built based on Islamic Sharia and the Khilafa State. This is a natural action to be said by Muhammadiyah cadres, who, although organizationally Muhammadiyah, do not support the establishment of the Khilafah State and tend to have moderate views. However, Muhammadiyah cannot fully control its cadres to have the same thoughts as organizational thoughts ${ }^{11}$.

\subsection{Pancasila With Islamic Values}

Returning to the Pancasila principle, there is no conflict with Islamic teachings from the Koran and Sunnah and any religious education in Indonesia. If we look in the Al-Quran, all the principles in Pancasila are also found in the Al-Quran. As a nation's philosophy of life, the essence of Pancasila's values has been lived and practiced by the Indonesian government since this state was not yet established. As contained in paragraph 4 of the 1945 Constitution, the formulation of Pancasila reflects the nation's philosophy and culture, including it, is derived from and inspired by the religious values and teachings of the Indonesian people.

Religion and Pancasila are two things that are inherent in the cultural values of Indonesian society. These two things are contradictory because religious values are embodied in the remainder of the Pancasila principles. In his presentation at the National Development Conference of Indonesia, Amin Abdullah stated that Islamic political thought in Indonesia is important to continue to be developed

11 Yulianto,Agus. 2017. Din Syamsuddin: Muhammadiyah Harus Jadi Gerakan Penengah. Republika.co.id. https://www.republika.co.id/berita/dunia-islam/islam-nusantara/17/02/22/olrdpt396-din-syamsuddin-muhammadiyah-harus-jadi-gerakan-penengah 
so that religion and Pancasila can go hand in hand to ward off upheaval such as the Arab Spring phenomenon that hit the Middle Eastern countries.

In Indonesia, Islam has a cultural correlation with Pancasila, which makes Islamic political thinking in Indonesia easier to implement. Islamic political thought is very difficult to develop in Middle Eastern countries. With Pancasila, Indonesia can develop this thought; it is easier to see the culture in Indonesia. This thought is important to prevent the Arab Spring from entering Indonesia. The challenge now is the complexity between religion and plurality in Indonesia.

As the religion that is embraced by the majority of this nation, Islam certainly has a very strong relationship with the values of Pancasila. This can be listened to from each of the precepts contained in the following Pancasila:

Pancasila first, "The One True God." Divinity is the principle of all religions. And the direction of the oneness of God is the core of Islamic teachings, known as the concept of monotheism. In Islam, monotheism must be believed in kaffah (totality) so that monotheism is not just a form of confession and statement. However, real actions must be proven, such as performing religious obligations, both in the context of vertical relationship to God (ubudiyyah) and a horizontal relationship with fellow human beings and all creatures (hablun minan nas).

\subsection{Ideological Variants Of Muhammadiyah Cadres}

Organizationally, Muhammadiyah is not against Pancasila as the nation's ideology. Still,considering that Muhammadiyah has cadres with various ideological variants, the consequence is that the attitude chosen by Muhammadiyah cadres is sometimes contrary to the views of the organization. Muhammadiyah members often question the opposition to Pancasila as the ideology of the Indonesian state at lower levels.

The diversity of views of Muhammadiyah residents is divided into 4 variants in the sosilog - religious perspective. Namely first: Muhammadiyah - sincere, second: Muhammadiyah - Kiai Ahmad Dahlan, third: Muhammadiyah - NU, fourth; Muhammadiyah - Marhaen.

They are Muhammadiyah members who agree with and accept religious plurality with the argument that understanding religious pluralism must be distinguished from religious majority and divergence because religious pluralism is more than a passive acknowledgment of the diversity of beliefs and other religions. 
Second, Muhammadiyah youths who firmly reject the discourse of pluralism, the argument used by religious pluralism, is a notion that teaches all religions to be true, and this is contrary to the belief that the truest religion with Allah is only Islam and nothing else. This means that from the two studies above, the data is understood that between the text and ideals with the reality of Muhammadiyah's religious, social behavior varies. In his writing, Sholihul Huda is a variant of religious ideology in Muhammadiyah from moderate to radical.

First, Muhammadiyah is the text of Muhammadiyah's socio-religious reality, which is very dynamic, which means that it will continue to experience the dialectic movement. Change can be changed and adjusted according to the times so that it is not considered stagnant, old-fashioned "traditional." Moreover, by carrying out the Islamic reform movement (Tajdid), it will increasingly influence the nature of Muhammadiyah people's hearts to be demanded to think and behave modernly. This requires the continuous re-reading of Muhammadiyah.

Second, the position of the socio-cultural structure of Muhammadiyah followers varies.At the beginning of its establishment, Muhammadiyah was mostly backed up by the majority of merchants and priyayi (abdi dalem Keraton Ngayogyokarto), then shifted to Civil Servants (PNS), especially teachers and lecturers who mostly lived in cities, so that Muhammadiyah developed faster in urban areas than in rural areas. In the next development, the preaching of Muhammadiyah began to target rural communities and various social communities starting from Commercial Sex Workers (PSK), Farmers, Laborers, Fishermen, Bloggers, Young Executives, Artist Entrepreneurs and so on. 4 This condition certainly has an impact on Muhammadiyah, they construct Muhammadiyah according to "nature of thinking" and its socio-cultural background, so that it has its color among Muhammadiyah.

Third, various understandings of Kiai Ahmad Dahlan's ideal thought which are linked to social reality. Muhammadiyah is a manifestation of Kiai Ahmad Dahlan's ideals in building an Islamic society based on the spirit of Islamic values, "compassion" and reform (tajdid). These ideals continue to be constructed with various methodologies and interests to find the ideal construction possible with the ideals of Kiai Ahmad Dahlan in answering society's problems. Because of the religion's methodology and interests, automatically the results of the construction of the understanding also vary. These variations certainly influence the ideal construction of Muhammadiyah. 
Fourth, different scientific paradigms and methodologies understand the social reality of Muhammadiyah with community problems contemporary. Muhammadiyah residents have various educational backgrounds, from not going to school to being a professor. This background polarization impacts the paradigm and methodology used in understanding and addressing problems in Muhammadiyah. This phenomenon can be observed that some Muhammadiyah members are still engaged in discussing the law of the Fajr Prayer Qunut, TBC, Tahlilan, Ziarah Kubur, Tingkepan, and so on. Even some have examined the internationalization of Muhammadiyah at the global level. The portrait above illustrates that the socio-cultural structure of Muhammadiyah members is not single. This condition naturally affects the polarization of understanding and religious attitudes within Muhammadiyah. That is, even though conceptually, the formulation of ideas and strategies for struggle (ideology) agreed together and singly through organizational decisions, but in the process of understanding varied ideologies, giving rise to varied socio-religious attitudes ${ }^{12}$.

\subsection{Discourse On Diversity And Tolerance}

Muhammadiyah, in its more than one century age range, has felt the dynamics of national life. There is no need to doubt the progress of building and filling the space of national life based on a shared frame based on the principles of tolerance and diversity from Muhammadiyah. It is then a very wise step for Muhammadiyah to give the theme of "Merekat Togetherness" in its annual method called Milad Muhammadiyah at the age of 105 . This theme means that Indonesia, born from the agreement of a predecessor, must be maintained to become a united country. Indonesia is a concrete example of a nation's plurality, which makes Indonesia a battleground for various kinds of ideologies that represent this plurality ${ }^{13}$.

However, lately, the issue of tolerance and radicalism has recently increased, which, according to some, has grown from year to year. There are also issues surrounding the anti-Pancasila, anti-diversity, anti-NKRI, polarization that

12 Huda,Sholihul, 2019. Varian Ideologi Keberagaman Di Muhammadiyah: dari Moderat Hingga Radikal. Pijarnwes.id. https://pijarnews.id/870/opini/2019/varian-ideologi-keberagamaan-di-muhammadiyahdari-moderat-hingga-radikal/

13 Purwata,Hery. 2015. Amien Rais Ajak Warga Muhammadiyah Berjihad. Republika.co.id.https://www.republika.co.id/berita/nasional/umum/15/05/14/noclta-amien-rais-ajak-warga-muhammadiyah-berjihad 
divides the nation, other forms of threats to Indonesia. The point of intolerance and radicalism, in particular to some extent, is associated with religion, especially Muslims.

However, it also needs to be examined carefully. That intolerance, radicalism, and all forms of threats to Indonesia objectively and comprehensively so as not to be partial, tendentious, and misleading. It is necessary to reconstruct concepts, thoughts, and parameters that can be discussed and formulated collectively about the phenomenon of intolerance, radicalism, and all forms of anti-diversity to avoid unilateral, black-and-white tendencies and only address one aspect and group.

Meanwhile, as a consequence of reforms and democratization options that are open in the midst of the swift flow of foreign powers and globalization that have entered the entire sphere of national life, there is now a process of liberalizing political, economic, and cultural experience which has a very complex impact on the life of the nation. This liberalization process shattered the Indonesian values based on religion, Pancasila, and culture that live in this nation's body. An egoistic, hedonistic, materialistic, transactional, greedy, and opportunistic orientation of life has torn apart togetherness and national and human life joints.

Damage to togetherness can also occur due to increasingly extreme economic inequality. If one percent of Indonesians are allowed to continue to control the 55 processes of national wealth and destroy the togetherness, it will further become a fire in the husk, which can lead to massive national disintegration. Negata must have the courage to uphold social justice to overcome this social gap. Do not let a handful of people with giant hands, greed, the power of money, and their influence in the power structure dominate Indonesia both openly and covertly if this country realizes Pancasila and national ideals together.

Social inequality and the greed of a small group of parties are as serious as radicalism and terrorism and other ideological threats, maybe even more dangerous. The government and political forces also need to be increasingly aware of these long-term threats. Believers will certainly remember Allah SWT's warning that damage on earth is caused by human hands and the destruction of a country because there are "al-mutrafun" figures who always practice anarchy, greed, and authority.

Therefore, it takes all parties' efforts to solve these national problems in a clear, objective, and comprehensive manner by putting the interests of the nation and state above everything. Building togetherness in a pluralistic society and 
full of crucial problems as described above is truly a steep and noble path that requires courage and jihad by the country's leaders who are free from interests and all forms of self-hostage. "A state is formed not only because of power but also because of the integral unity of all the forces of society in the national entity," said the famous philosopher Spinoza. Therefore, all parties, both the government and political forces, and all nation components are required to have a strong commitment to cement togetherness when there is a crack in this nation's body.

Therefore, the author will try to describe the role of Muhammadiyah as a large organization with many followers in Indonesia, which certainly has a central role in stemming the flow of radicalism and intolerance. This analysis will look at the distribution of diversity that Indonesia has and the challenges of Muhammadiyah to diversity in Indonesia. There are at least two issues of diversity in Indonesia and the role of Muhammadiyah in maintaining diversity and tolerance, not only religious patience but tolerance within Muslims themselves. First, the variety or diversity of different religions and diversity within Muslims.

\subsection{Interreligious Diversity}

Muhammadiyah, in looking at the issue of diversity and tolerance between members of the Muslim world, tends to use creative ways so that it can foster harmony among diverse people rather than aggressive ways, which tend to cause riots in religious communities; this can be seen from the research of Nadlifah Muhammadiyah in the Humanist Education Frame (Humanistic Psychology Review ) (2016), which quoted Alwi Syihab's statement about Muhammadiyah according to his business ${ }^{14}$.

With a more competitive approach than an aggressive approach in disseminating the mission of preaching, Amar makruf Nahi Munkar Muhammadiyah will foster a more harmonious atmosphere. On the one hand, the effort to preach which when Ahmad Dahlan founded the Early Age of Muhammadiayh, one of the points was to stem the flow of Christianization and, on the other hand, to maintain diversity and harmony between religious communities.

Alwi Shihab describes that Muhammadiyah as an Islamic movement, Amar makruf nahi munkar, has a great degree of criticism towards the penetration

14 Nadlifah, 2016. Muhammadiyah Dalam Bingkai Pendidikan Humanis. Al Bidaya: Jurnal Pendidikan Dasar Islam, Vol.8(2), 140 - 154. 
of the very massive spread of Christianization so that to compete with the massiveness of Christianization, Muhammadiyah chooses the competitive path, which is trying to support the Indonesian people at the level of grass-root so that it touches the needs of many people, which is done by establishing various educational institutions from the childhood level to higher education as a form of Muhammadiyah charity efforts.

The main principle regarding Muhammadiyah's view of diversity can be seen that Muhammadiyah believes that social life is God's nature. This is by the Muqaddimah of Muhammadiyah's Articles of Association on the second principle of "Human life is a society." These ideas are formulated as follows: "Living in society is the sunnah (qudrat iradat law) of Allah on human life in this world." The reality of society is very pluralistic; there are various ethnic groups, races, and groups. Therefore, if a company is a necessity, then society's plurality in it is also a necessity. Muhammadiyah believes that the majority is a necessity that exists and has.

\subsection{Diversity In Muhammadiyah Charities}

Then Commitment to Diversity What Muhammadiyah has done is to establish an educational institution that is not only intended for Muslim students and students, but non-Muslim students have the right to the same education as others in Muhammadiyah educational institutions. Diversity and tolerance between religious communities can be seen at the University of Muhammadiyah Kupang, where almost $75 \%$ of students have religions other than Islam. The Science of Government of the Muhammadiyah University of Yogyakarta made a study entitled "The Bright Cross under the Sunlight: The Politics of Recognition of Diversity of Religion, Culture and Personality Values through Multicultural Education." By making the University of Muhammadiyah Kupang as the object of research, it was found that the majority of UMP students chose to study at UMP because the image of Muhammadiyah was very tolerant. Over the years, this culture of tolerance was maintained.

With full awareness, as a result of Muhammadiyah's commitment to tolerance and diversity, Muhammdiyah through the higher education council on 3-4 November 2017 designed AIK (Al-Islam and Kemuhammadiyahan) specifically for non-Muslims who are studying at Muhammadiyah institutions. Because AIK, which is often accepted by non-Muslim students, is the same as AIK given to students at PTM in general, namely AIK 1 (Humanity and Faith), AIK 
2 (Worship, Akhlak and Muamallah), AIK 3 (Islam and Kemuhammadiyahan), and AIK 4 (Islam and Science)

By choosing the education path as a space to accommodate minority groups, Muhammadiyah's efforts deserve to be appreciated. This is because education is a space where inclusive ideas are located. It is very appropriate to foster honest thoughts, strategies for building peace, and an understanding of religious modernity. In the practice of spiritual life, the leaders of the largest organizations in Indonesia, such as Nahdhatul 'Ulama and Muhammadiyah, always campaign about the importance of a peace-loving Islam. Regardless of the different strategies to carry out "deradicalization," Said Aqil Siraj and Din Syamsuddin have worked hard together to build an Indonesian Islamic society that is far from the sentiments of Islamic ideology.

\subsection{Diversity Within the Muslim Community}

Since the inception of Muhammadiyah, it has always been faced with complex religious realities so that it will be able to influence Muhammadiyah's vision and mission in the future, according to Syamsodin's (2010) research, on KH. As'ad Syamsul Arifin regarding. Then not only Muhammadiyah, Indonesia, in the post-1998 reformation, was increasingly faced with Muslims' extraordinary internal dynamics. In this era, many new Islamic organizations emerged, many of which were in groups other than formal organizations. In the birth of the groups that had just been discussed also appeared very diverse Islamic ideas. Thus the classification and grouping of the Isalm community in Indonesia are getting wider, and the frequency is increasingly diverse. The plurality and diversity of Muslims are increasingly unavoidable. Because considering that Muslims in Indonesia are not homogeneous and, in fact, very heterogeneous from the most conservative to progressive from moderate to extreme left and right. Indonesian Muslims, since the birth of organizations that carry the name Islam, cannot be separated from conflicts or religious understandings. Even in the internal divisions of the organization, there are always differences and conflicts ${ }^{15}$.

Like the book Defending Islam Murni (2016), examining the Islamic point of view of Muhammadiyah cadres, from the most conservative to the most progressive, from the most moderate to the most ecstatic, all are complete in Muhammadiyah. In terms of diversity or diversity within Muslims' internal body,

15 Syamsodin. 2010. Khitah Pasantren Perspektif K.H.R As'ad Syamsul Arifin. Sekolah Tinggi Agama Islam Negeri Salatiga. 
Muhammadiyah will at least face several problems, including Islamic Purification Discourse, Islamic Political Party Discourse. In terms of Islamic purification: Muhammadiyah is faced with the reality of various understandings and practices of the diversity of Islamic societies in Indonesia, which often mix Islamic culture with ancestral cultures that existed before Islam arrived in Indonesia. The second problem, Muhammadiyah, will clash with the penetration of missionaries and liberalism movements that get strong support from rulers in other countries. In the penetration of Christians, it can be seen in the dissertation of doctoral Alwi Shihab "Blocking the flow: the response of the Muhammadiyah movement to the penetration of Christian missions in Indonesia, which is written that there are at least two interesting things." Christian missionary mission to spread his religion. The two socio-religious issues above their mouth are tolerance, especially those with religious characteristics. Internally, Muhammadiyah is dealing with traditionalist groups that still adhere to the ancestral culture (which destroys Islamic values) so that it needs the purification of Islamic teachings, and on the external side, Muhammadiyah is dealing with Christianization and liberalization of various aspects of life ${ }^{16}$.

\section{Conclussion}

From this discursive or discourse research, several conclusions can be given, among others. First, the contribution of Muhammadiyah related to the discourse of Pancasila and nationalism is quite clear from its history since its founding, which has the same values as Budi Utomo regarding national development efforts, namely through education. From Muhammadiyah's education, Islamic and Indonesian values are both maintained and strengthened. It is clear that the Muhammadiyah organization has a very large contribution in supporting the Indonesian nation and state system that is placed on the Pancasila system, as evidenced by several products of Muhammadiyah thought that have been systematized over the last five years, such as the idea of "Pancasila State" as Darul ahd wa al-Shahadah, Indonesia. Progressing, progressing Islam, and some of the followers of Muhammadiyah's beliefs, such as the Islamic Life Guidelines for Muhammadiyah members, include guidelines for the nation and state, which is certainly proof of Muhammadiyah's commitment to continue to oversee the development and ideology of the Indonesian government.

Second, Pancasila's acceptance as the state ideology must be admitted that there is a diverse spectrum. This can be shown from elites and Muhammadiyah

16 Pradana, Boy. 2016. Membela Islam Murni. Suara Muhammadiyah. Yogyakarta. 
cadres' views and thoughts, who are often different because Muhammadiyah is built on a collective-collegial system, which all have the same voice and right to determine the net flow of Muhammadiyah organizations. There is a very strong tradition of autonomy and discourse within the Muhammadiyah organization, especially regarding political attitudes and relations with the government regime. From the research above, it can be concluded that the Muhammadiyah elites at the mid-level agree with Pancasila. However, it cannot be denied that Muhammadiyah cadres have various thought variants, which can be ascertained that they are not single, let alone dealing with a regime of power that changes its relation to Islam and Islamic civil society.

\section{Reference}

Efendi,David. Politike Elite Muhammadiyah:Studi Tentang Fragmatisme Elit Muhammadiyah. Yogyakarta: Revia Cendekia, 2010.

Huberman, Milas. Analisis Data Kualitatif. Jakarta: Universitas Indonesia Press, 1992. Huda, Sholihul. "Varian Ideologi Keberagamaan Di Muhammadiyah: Dari Moderat Hingga Radikal.” pijarnews, 2019. https://pijarnews.id/870/opini/2019/ varian-ideologi-keberagamaan-di-muhammadiyah-dari-moderat-hinggaradikal/.

Khamid, Nur. "Bahaya Radikalisme Terhadap NKRI." Millati Journal: Of Islamic Studies and Humanities Vol 1, no. No 1 (2016): 123-52.

Moleong, Lexi. Qualitative Research Methodology. Jakarta: PT. Remaja Rosdakarya, 2007.

Nadlifah. "Muhammadiyah Dalam Bingkai Pendidikan Humanis." Al Bidaya: Jurnal Pendidikan Dasar Islam Vol 8, no. No 2 (2016): 140-54.

Nashir, Haedar. Mubammadiyah Gerakan Pembaharuan Negara. Yogykarta: Suara Muhammadiyah, 2010. 40-46.

Nashir, Haedar. "Muhammadiyah Gerakan Pembaharuan Negara." Suara Muhammadiyah. Yogykarta: Suara Muhammadiyah, 2010. 46-47.

Nashir, Haedar. "Muhammadiyah Gerakan Pembaharuan Negara." Suara Muhammadiyah. Yogykarta: Suara Muhammadiyah, 2010. 50-52

Pradana, Boy. Membela Islam Murni. Yogyakarta: Suara Muhammadiyah, 2016.

Purwata, Hery. “Amien Rais Ajak Warga Muhammadiyah Berjihad.” Republika. co.id, 2015. republika.co.id.https://www.republika.co.id/berita/nasional/ umum/15/05/14/noclta-amien-rais-ajak-warga-muhammadiyahberjihad. 
Slamet, Sutrisno. Filsafat Dan Ideologi Pancasila. Yogyakarta: Andi, 2006.

Suara Muhammadiyah. "Matan Keyakinan Dan Cita - Cita Hidup." suaramuhammadiyah.id, 2020. https://www.suaramuhammadiyah. id/2020/07/04/matan-keyakinan-dan-cita-cita-hidup/.

Syamsodin. "Khitah Pasantren Perspektif K.H.R As'ad Syamsul Arifin.” Sekolah Tinggi Agama Islam Negeri Salatiga, 2010.

Syamsul, Hidayat. "Negara Pancasila Sebagai Daruk"Ahdi Wasy Syahadah Wawasan Dan Kontribusi Muhammadiyah Bagi NKRI.” Jurnal Tajdid Vol 14, no. No 1 (2016): 12-17.

Yulianto, Agus. "Din Syamsuddin: Muhammadiyah Harus Jadi Gerakan Penengah.” Republika, 2017. https://www.republika.co.id/berita/ dunia-islam/islam-nusantara/17/02/22/olrdpt396-din-syamsuddinmuhammadiyah-harus-jadi-gerakan-penengah. 
